\title{
BEHAVIOURAL EFFECTS OF SHORT-TERM TOTAL FOOD RESTRICTION IN RATS
}

Dragica Selakovic ${ }^{1^{*}}$ and Jovana Joksimovic ${ }^{1^{*}}$

${ }^{1}$ Faculty of Medical Sciences, University of Kragujevac, Kragujevac, Serbia

'Dragica Selakovic and Jovana Joksimovic contributed equally (50\% each) to this work, and both should be considered first authors

\author{
UTICAJ KRATKOTRAJNOG POTPUNOG PREKIDA \\ UNOSA HRANE NA PONAŠANJE PACOVA \\ Dragica Selaković i Javana Joksimović ${ }^{1}$ \\ ${ }^{1}$ Fakultet medicinskih nauka, Univerzitet u Kragujevcu, Kragujevac, Srbija \\ "Dragica Selaković i Jovana Joksimović su učestvovale podjednako (50\% svaka) u izradi ovog rada, pa se obe mogu smatrati prvim autorom
}

\section{ABSTRACT}

Reducing food intake can decrease anxiety indices in rats. The aim of this study was to evaluate the influence of short-term (48 hours) total food restriction on the behavioural characteristics, the motor coordination and balance, of rats. Three-month-old male Wistar albino rats $(n=20)$ weighing 350-400 $g$ were divided into a control group (food and water intake ad libitum) and an experimental group (total food restriction 48 hours before testing). Behavioural studies were performed using the open field, elevated plus maze, Barnes maze, beam walking, evoked beam walking and linear locomotor tests. The total distance moved, the velocity, the movement and the frequency in the centre zone of the open field were significantly higher in the treated group. The cumulative duration in the centre zone of the open field did not significantly increase in the treated group. The number of entries into the open arms, the total time spent in the open arms and the total distance moved in the elevated plus maze significantly increased with no change in the velocity in the food-restricted animals. The 48 hours of total food restriction did not affect the Barnes maze test parameters or the parameters of the linear locomotor test. The velocity recorded during the beam walking test was not affected by the food restriction, but the velocity recorded during the evoked beam walking test significantly decreased in the treated group. In summary, short-term total food restriction did not produce significant changes in the physical performance of rats but did result in anxiolytic-like behaviour accompanied by food-seeking behaviour due to enhanced motivation to forage for food.

Keywords: food restriction, behaviour, anxiety, rat

\section{SAŽETAK}

Redukcija unosa hrane može dovesti do smanjenja anksioznosti kod pacova. Cilj ovog istraživanja je bio da se ispita uticaj kratkotrajnog (48 h), potpunog prekida unosa hrane na ponašanje, kao i motoričku koordinaciju i ravnotežu kod pacova. Tri meseca stari, muški Wistar albino pacovi $(n=20)$, težine 350-400 g su podeljeni u kontrolnu grupu (unos hrane $i$ vode ad libitum) i eksperimentalnu grupu - potpuni prekid unosa hrane $48 \mathrm{~h}$ pre testiranja. Bihejvioralna istraživanja su sprovedena uz korišćenje testova: „otvorenog polja”, „uzdignutog krstastog lavirinta”, Barnsovog lavirinta, „hodanja po gredi”, „izazvanog hodanja po gredi "i linearnog lokomotornog testa. Ukupno predeno rastojanje, brzina, kretanje i frekvencija ulazaka u centralnu zonu „otvorenog polja” su bili značajno veći u tretiranoj grupi. Ukupno vreme provedeno u centralnoj zoni „otvorenog polja” se nije značajno povećalo u tretiranoj grupi. Broj ulazaka u otvorene krake, ukupno vreme provedeno u otvorenim kracima i ukupno pređeno rastojanje u „uzdignutom krstastom lavirintu" su bili značajno povećani, dok se brzina nije menjala kod životinja bez unosa hrane. 48 h potpunog prekida unosa hrane nije imalo uticaja na parametre testa Barnsovog lavirinta, kao ni na parametre linearnog lokomotornog testa. Brzina registrovana kod testa „hodanja po gredi” se nije menjala usled restrikcije unosa hrane, ali se brzina registrovana kod testa " izazvanog hodanja po gredi" značajno smanjila u grupi tretiranih životinja. Sumarno, kratkotrajni potpuni prekid unosa hrane nije izazvao značajne promene fizičke sposobnosti pacova, ali je na ponašanje ispoljio efekte koji podsećaju na anksiolitičko dejstvo, uz obrasce koji podsećaju na traženje hrane usled povećane motivacije da se obezbedi hrana.

Ključne reči: ograničenje unosa hrane, ponašanje, anksioznost, pacov

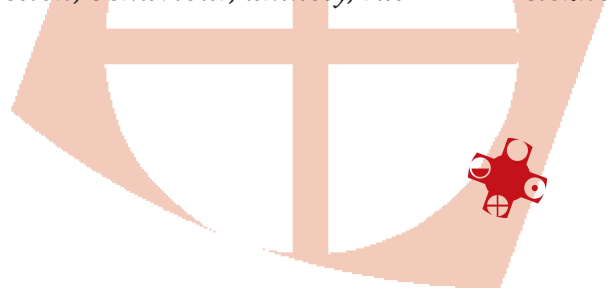




\section{INTRODUCTION}

In a variety of animal species, calorie restriction is a well-known factor in and the most effective and reproducible intervention for increasing lifespan $(1,2)$, and it is a cancer-prevention regimen in experimental carcinogenesis models (3). Restricted food intake can also be beneficial via its control of weight gain, as well as the improvement in insulin sensitivity in type 2 diabetes (4). Additionally, calorie restriction can prevent cardiovascular diseases $(5,6)$. Some behavioural tests have indicated that reducing food intake can decrease indices of anxiety in animals (7).

There are different regimens for calorie restriction in animal models. During a chronic calorie restriction diet, the nutrient composition, that is, the vitamins, minerals and proteins, must be maintained to prevent undernutrition or malnutrition (8).

A study by Ross showed that rats fed a high-protein/ high-carbohydrate ad libitum diet had lower mortality rates at younger ages than those fed a nutrient-poor, low-protein/ low-carbohydrate ad libitum diet. However, the animals with the poor nutrition diet had lower mortality rates than the animals with the rich nutrition diet. This finding implies that a high caloric intake is appropriate for growth, development and reproduction, but it does not provide a protective influence against age-related diseases (9).

Regarding chronic food restriction, it is known that maintaining the body weight at $80 \%$ led to behavioural changes and physiological stress (corticosterone level), but water restriction did not have that effect (10).

A whole battery of tests is now available to evaluate the behavioural characteristics of laboratory animals. Some of the tests are better suited for estimating the physical performance of the animals (eg, beam walking test, rotarod, and grip test), while other tests are often used to evaluate emotionality/anxiety (eg, open field test and the elevated plus maze test) or memory and learning (eg, the Barnes test and the Morris water maze test).

In 1966, a direct observation of rat activity during food deprivation confirmed that food-restricted animals showed improved physical performance, as indicated by increased locomotor activity and a lower frequency of resting; this physical change was more distinct in younger animals (11).

Various tests have been used to evaluate the effects of food restriction on memory. Depending on the protocol of the trials, the results have demonstrated that a shortterm restriction of food intake had a beneficial effect on the spatial memory in male rats, with the opposite effect in female rats (12). However, two weeks of $40 \%$ calorie restriction did not influence the spatial memory during a $\mathrm{Y}$ maze test (13), whereas a lifelong hypocaloric diet, which started in young animals, was able to prevent the further decline in the memory test (Morris water maze test) that occurs between middle age and old age (14).

Epidemiological studies indicate that anxiety disorders are the most common psychiatric disorders (15). Anxiety can be defined as "a physiological, psychological, and behav- ioural state induced in animals and humans by a threat to well-being or survival, either actual or potential" (16). The behaviour patterns of anxiety vary from ongoing behaviours, such as explorative activity and feeding, to defensive patterns (eg, escape). Numerous behavioural tests allow us to estimate the ability of animals to cope with unexpected situations and adverse environments. It is well known that the calorie restriction state in animals may provide a model for investigating the neurobiology of anxiety.

The open field and elevated plus maze tests are two widely used models of emotionality/anxiety. The open field test is a useful animal model of anxiety-like behaviour. This test has been used to estimate the "emotional reactions" of rats since 1936 (17)is and is currently one of the most popular procedures in animal psychology. The open field consists of a novel large arena containing an aversive central area (18). The animal (mainly a rodent) is usually placed in the centre of the arena to encounter a completely new environment. Anxiety-like behaviour is characterised in the open field as walking close to the walls (cumulative duration in border zone), a behaviour called thigmotaxis. Additionally, a few additional parameters are usually considered to be indicators for anxiety-like behaviour in the open field test, such as decreases in the cumulative duration in the centre zone and the number of entries in centre zone. In contrast, an increase in the total distance moved in the central zone or in the time spent in the central part of the device without an alteration of the total locomotor or vertical exploration can be interpreted as an anxiolyticlike effect; the opposite effect, that is, a decrease in these variables, is associated with anxiogenic effects (19). Foodrestricted rats showed enhanced activity in the centre zone of the open field (10). Anxiolytic drugs can increase the total locomotor and vertical exploration activity in the open field (19).

The elevated plus maze test, a well-known test for examining anxiety, is based on the conflict displayed by rats between the tendency to explore a new environment and the fear of open elevated areas (20). Placing the rat on the central platform on the elevated plus maze can evoke both the exploratory drive and the fear drive, thus generating an approach-avoidance conflict behaviour. In the elevated plus maze, the percentage of entries and the time spent in open arm are measures of anxiety, whereas the number of total arm entries (open + closed) is an indicator of the overall activity (21). From the central zone of the elevated plus maze, rats show head-dipping exploratory activity, as well as attend/approach responses toward the open arm. It should be noted that explorative activity can be enhanced by some factors, such as food or water deprivation. Studies on the effects of anxiolytic drugs must verify that a given treatment does not act on such variables before reaching a conclusion about the possible effects on anxiety-like behaviours (19). Heiderstadt showed that male rats that received approximately $40 \%$ of the amount consumed by freely fed animals, or a calorie restriction of $60 \%$, had increased explorative activity and ambulation in the open field test (10). Addi- 

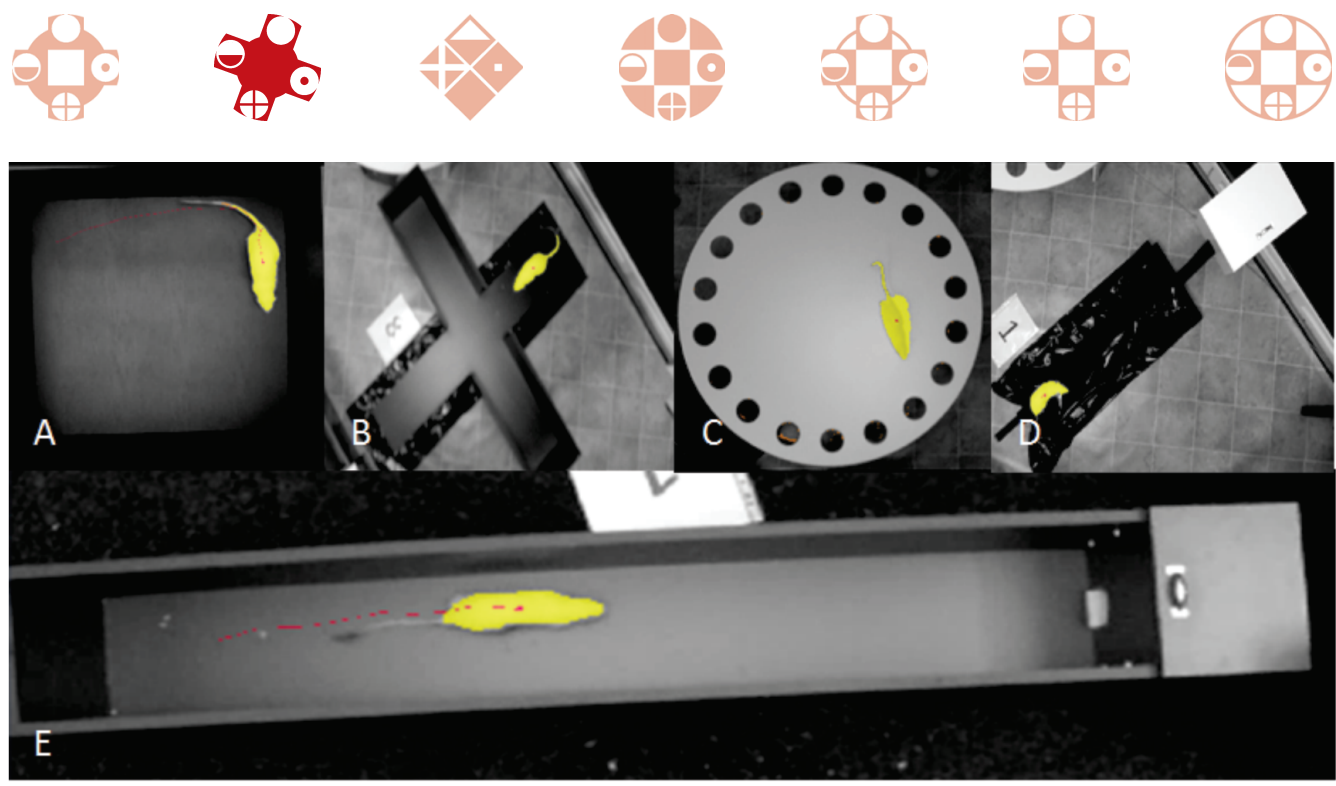

Figure 1. Open field (A), Elevated plus maze (B), Barnes maze (C), Beam walking (D), and Linear locomotor (E) tests.

tionally, male rats that maintained $85 \%$ of their body weight compared with that of control animals showed more entries into the open arms and a greater percentage of time in the open arms of the elevated plus maze (22). Three weeks of calorie restriction (75\% of the usual voluntary food intake) in rats led to more entries into the anxiety-provoking (open) arms, indicating less anxiety (23).

In our research, we examined how short-term (48 hours) total food restriction influences the behavioural characteristics, as well as the motor coordination and balance, of rats.

\section{MATERIAL AND METHODS}

\section{Animals}

Three-month-old male Wistar albino rats $(n=20)$ weighing 350-400 g were used. The animals were housed in controlled standard environmental conditions of temperature $\left(23 \pm 1{ }^{\circ} \mathrm{C}\right)$ and light $(12 / 12 \mathrm{~h}$ light/dark cycle), and the rats had free access to food and water until the groups were separated. The animals were divided in two groups (10 animals in each group). The control group had ad libitum access to food and water, and food intake of the experimental group was restricted for 48 hours before testing. The rats were placed in the testing room for $1-2 \mathrm{~h}$ prior to the initiation of each training and/or testing session. All research procedures were carried out in accordance with European Directive for welfare of laboratory animals $\mathrm{N}^{\circ} 86 / 609 / \mathrm{EEC}$ and principles of Good Laboratory Practice (GLP) approved by Ethical Committee of the Faculty of Medical Sciences, University of Kragujevac, Serbia.

\section{BEHAVIOURAL STUDIES}

\section{Open field test}

One of the tests that measures the general motor activity of animal is the open field test. This test may be used to evaluate potential motor deficits, and the moving pattern in the arena shows information about anxiety-like states. The time spent in the centre arena of the open field was determined as the major index for anxiety, and more ambulation towards the centre arena of the open field reflected less anxiety. The movements of the rats were recorded using a digital video camera centrally mounted $150 \mathrm{~cm}$ above the open field. The activity of the rats was recorded for a period of 5 minutes and then analysed. The apparatus consisted of a square arena (60 x $60 \times 30 \mathrm{~cm}$ ) made of black wood (Fig. 1A). During the trials, the experimenter was not present in the test room. At the beginning of a test, each rat was placed in the centre of arena. The following parameters were scored: total distance moved (TDM, cm), velocity ( $\mathrm{cm} / \mathrm{s})$, movement, frequency in centre zone and cumulative duration in centre zone. The frequency in the centre zone and cumulative duration in the centre zone are considered indicators of an anxiolytic-like effect $(10,19)$. At the end of each session, the rats were removed from the open field, and the experimental chamber was thoroughly cleaned with water and ethanol (70\%) to remove possible interfering scents. The behaviour of the animal in the open field was tracked by video using Ethovision software [version XT 10 base], a video tracking system that automatically records behavioural experiments [Noldus Information Technology, the Netherlands] (Fig. 1A).

\section{Elevated plus maze}

Anxiety-like behaviours were evaluated using the elevated plus maze test. This test can determine the emotional reactivity of animals by generating a conflict between the secure parts of the maze ( 2 enclosed arms) and the aversive parts of the maze (open arms). The elevated plus maze for rats consisted of two open $(50 \times 20 \mathrm{~cm})$ and two enclosed arms $(50 \mathrm{x}$ $20 \times 30 \mathrm{~cm}$ ) and an open roof; the entire maze was elevated $100 \mathrm{~cm}$ from the floor (Fig. 1B). Each rat was placed in the centre of the elevated plus maze with its head facing toward the open arm and was given 5 minutes for free exploration. During the 5 minutes of the test, the number of entries (frequency) into the open arms and the total time spent in open arms (cumulative duration) of the maze, total distance moved $(\mathrm{TDM}, \mathrm{cm})$ and velocity $(\mathrm{cm} / \mathrm{s})$ were recorded. The number 
A

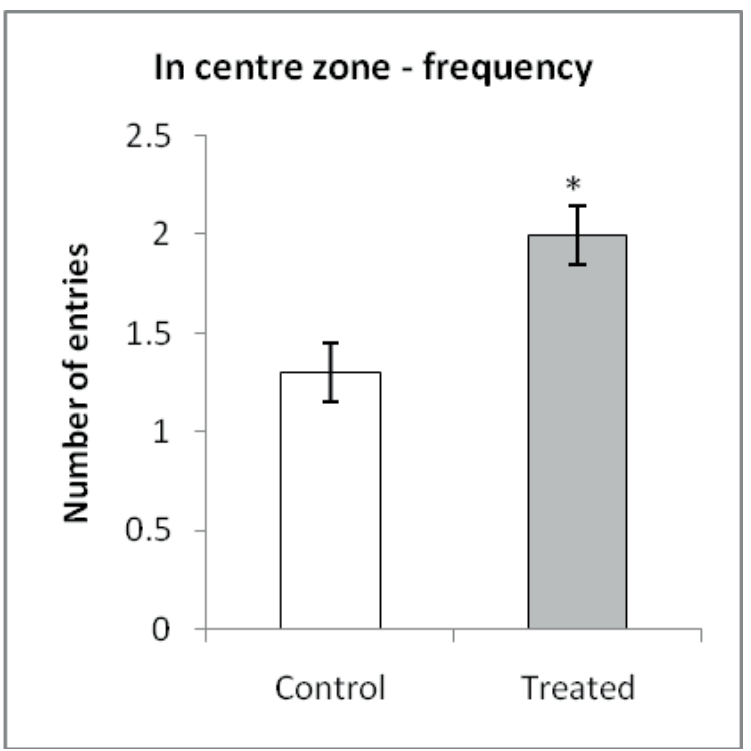

$\mathrm{C}$

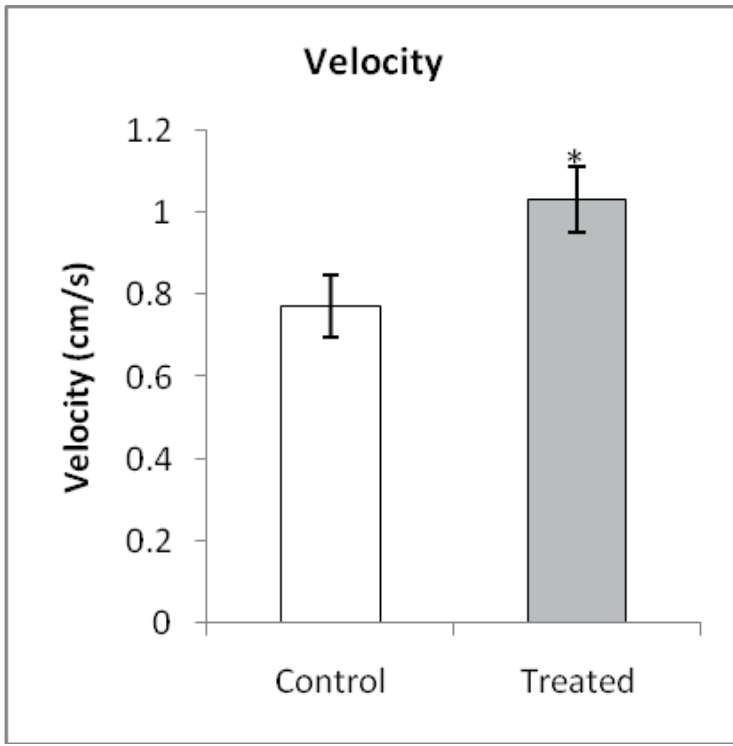

E

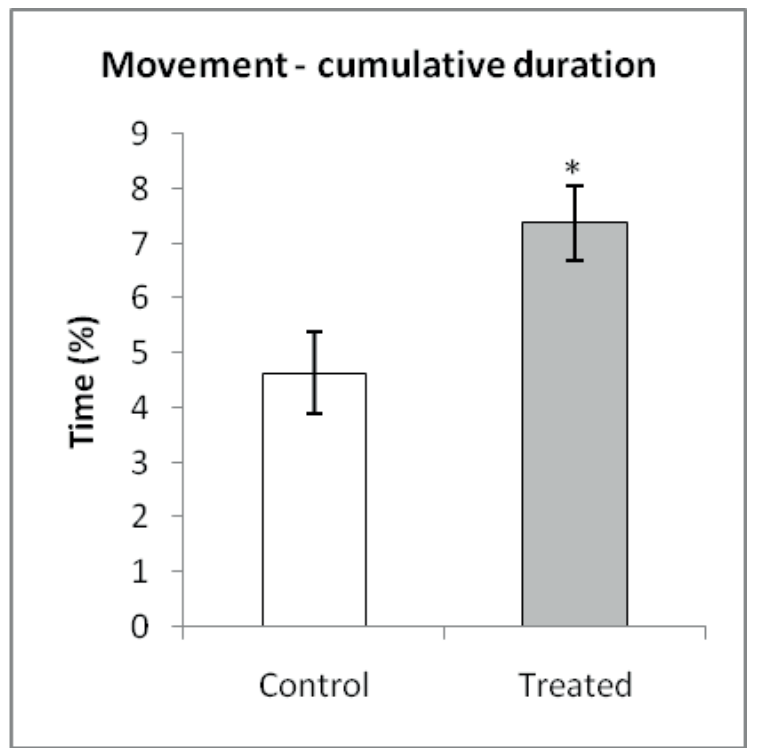

Total distance moved

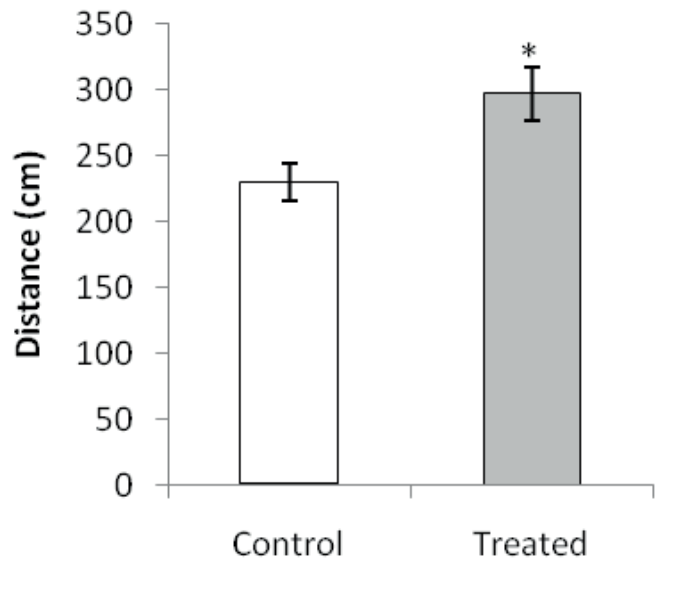

$\mathrm{D}$

\section{In centre zone - cumulative} duration

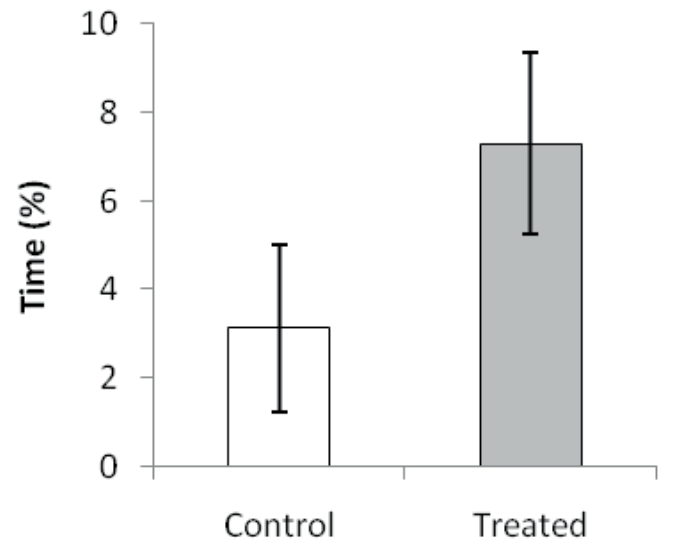

Figure 2. Parameters calculated from the open field test (Mean \pm SEM, * denotes a significant difference $p<0.05$ ). The food intake was completely restricted for $48 \mathrm{~h}$ in the treated animals. 
of entries and the cumulative duration in the open arms are considered indicators of an anxiogenic effect $(20,24)$. The activity of the rats was recorded using a digital video camera (resolution of 30 samples per second) centrally mounted 250 $\mathrm{cm}$ above the elevated plus maze. The behaviour of the animal in the elevated plus maze was tracked by video using Ethovision software [version XT 10 base], a video tracking system that automatically records behavioural experiments [Noldus Information Technology, the Netherlands] (Fig. 1B).

\section{Barnes maze}

The Barnes maze is a spatial learning and memory task that requires subjects to escape from a brightly lit area and learn the location for escaping from the box under one of the holes. The task relies on the innate preference of rodents for dark, enclosed spaces over open areas. The Barnes maze (25) consists of a flat, circular disk (122,5 $\mathrm{cm}$ in diameter, suspended $70 \mathrm{~cm}$ off the ground) with 18 holes $(10 \mathrm{~cm}$ in diameter) around its perimeter that permit the subject to exit the maze into an escape box (Fig. $1 C)$. Animals learn the location of an escape hole using high contrast spatial cues (2 large yellow stars on the black wall) fixed on one wall of the room. The Barnes maze does not involve swimming and is therefore considered less anxiogenic than the Morris water maze (26). On the day before the formal testing began, the rats were transported in their home cages to the central room of the testing suite and were allowed to acclimate for approximately $1 \mathrm{~h}$. Testing began by placing animal in the centre of a circular platform. The animal was monitored as it found its way from the centre of the platform to an escape hole. Trials were recorded using a digital video camera (resolution of 30 samples per second) mounted centrally $250 \mathrm{~cm}$ above the Barnes maze. The following parameters were estimated: time to find escape box in the first run, time to find escape box in the second run, distance to find escape box in the first run, distance to find escape box in the second run, velocity of the first run, velocity of the second run, percentage of shortening of distance moved to escape box between two runs of each rat, percentage of shortening of time to find escape box between two runs, percentage of increase in the velocity between two runs. The behaviour of the animal in the Barnes maze was tracked by video using Ethovision software [version XT 10 base], a video tracking system that automatically records behavioural experiments [Noldus Information Technology, the Netherlands] (Fig. 1C).

\section{Beam walking test}

The beam walking test was used to assess motor coordination, integration (27), balance performance (28) and motor skills. The beam walking apparatus consisted of a rectangularly shaped base. In this test, the ability of rats to pass through the beam to reach a goal box is evaluated. A white wooden box $(20 \times 20 \times 20 \mathrm{~cm})$ with a black hole served as a nest for motivating the animal to cross the beam. A stainless steel, squared, rubber-topped beam $(100 \times 3 \times 2 \mathrm{~cm})$ was fixed between the base of the goal box (100 cm above the floor) and a vertical stainless steel pole $(60 \mathrm{~cm}$ above the floor). The doweled rod was graduated from 0 to $50 \mathrm{~cm}$. The whole apparatus was placed above cushions, which protected the fallen animals from injury (Fig. 1D). Rats were pre-trained to cross the beam. On the day of the test, four trials were performed before recording the results. The interval between trials was 15 minutes. At the start of the trial, the rat was placed at the end of the beam opposite to the goal box. The goal was to accustom the rats to the beam and to allow them to become aware of the presence of the goal box at the end of the beam. In this test, the number of forelimb and hind limb foot faults, number offalls from the beam and time to cross the beam were recorded, and then the velocity $(\mathrm{cm} / \mathrm{s}$ ) was calculated (for defined distance). A fault was defined as any foot slip off the top of the surface of the beam or any limb use on the side of the beam. The beam walking test was conducted under the proper conditions of silence and illumination. The behaviour of the animal in the beam walking test was tracked by video using Ethovision software [version XT 10 base], a video tracking system that automatically records behavioural experiments [Noldus Information Technology, the Netherlands] (Fig. 1D).

\section{Evoked beam walking test}

This test was performed using the same apparatus as for the beam walking test. Rats were pre-trained to cross the beam using the same protocol as for beam walking test. At the start of the trial, the rat was placed at the end of the beam opposite to the goal box, while the experimenter started tapping (every 3 seconds) with a metal stick at the base of the stainless steel pole while rat traversed the beam (anxietyprovoking pattern). The tapping was performed until the rat reached the goal box. The recorded parameters in this test were the number of forelimb and hind limb foot faults, number of falls from the beam and time to cross the beam, and then the velocity $(\mathrm{cm} / \mathrm{s})$ was calculated (for defined distance). A fault was defined as any foot slip off the top of the surface of the beam or any limb use on the side of the beam. The velocity (relative to the previously performed beam walking test) was used as an indicator of anxiety. The beam walking test was conducted under proper illumination.

\section{Linear locomotor test}

A linear locomotor test was used to assess motor coordination and motor skills. The apparatus consisted of an enclosed rectangular box $(100 \times 20 \times 30 \mathrm{~cm})$ with start and goal boxes $(20 \times 20 \times 30 \mathrm{~cm})$ at the ends (Fig. 1E). In this test, the time to reach the goal box was recorded, and then the velocity $(\mathrm{cm} / \mathrm{s})$ was calculated (for defined distance). Using Ethovision software, the floor of the arena was virtually divided into three equal zones (centre, right and left) to evaluate the linearity of the animal locomotor while moving from the start box to the goal box using the zone transitions frequency. The behaviour of the animal during the linear locomotor test was tracked by video using Ethovision software [version XT 10 base], a video tracking system that automatically records behavioural experiments [Noldus Information Technology, the Netherlands] (Fig. 1E). 
A

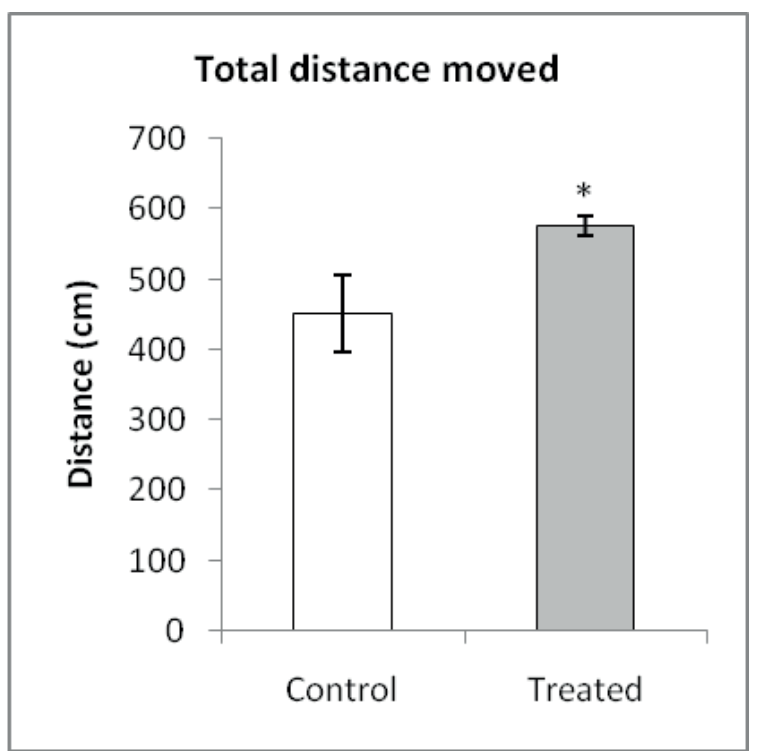

C

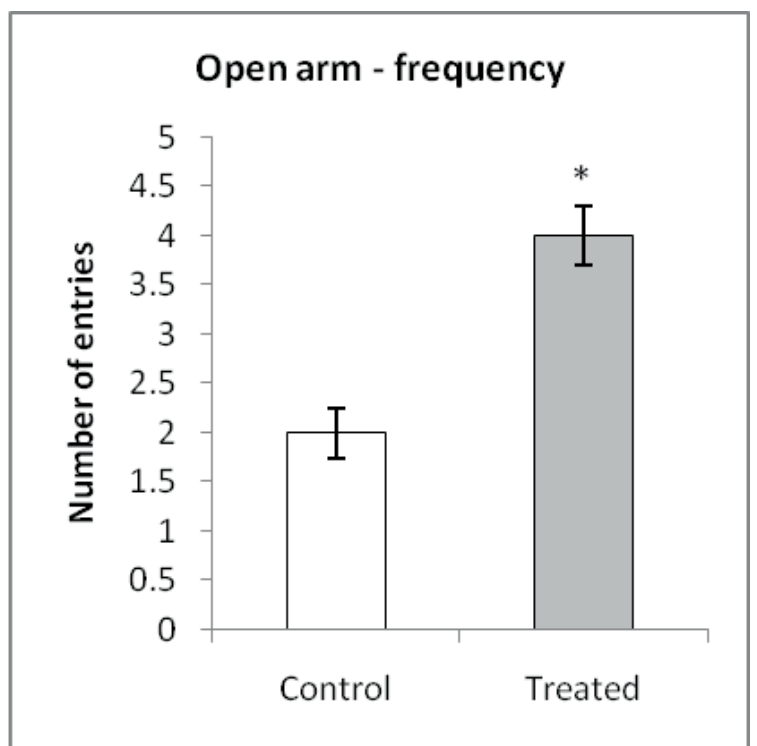

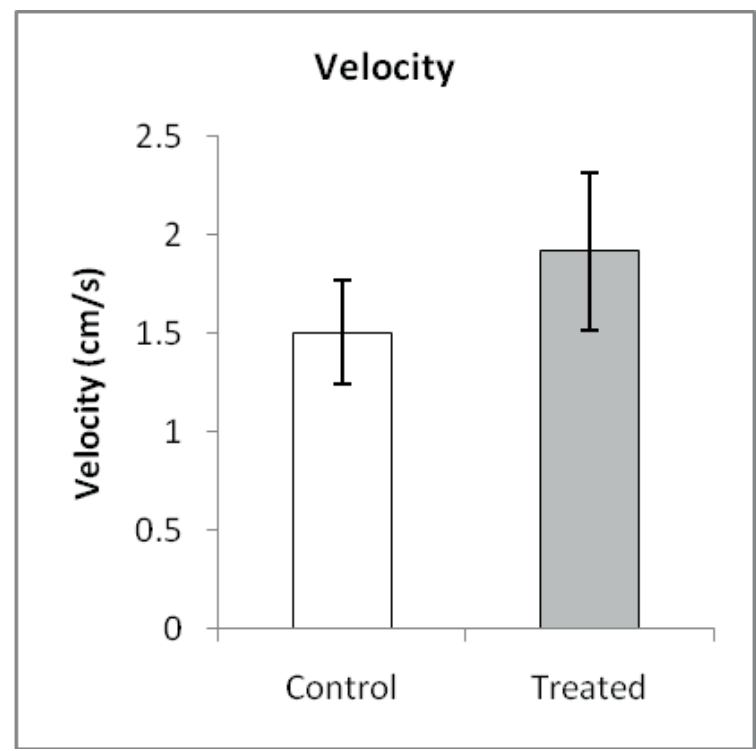

$\mathrm{D}$

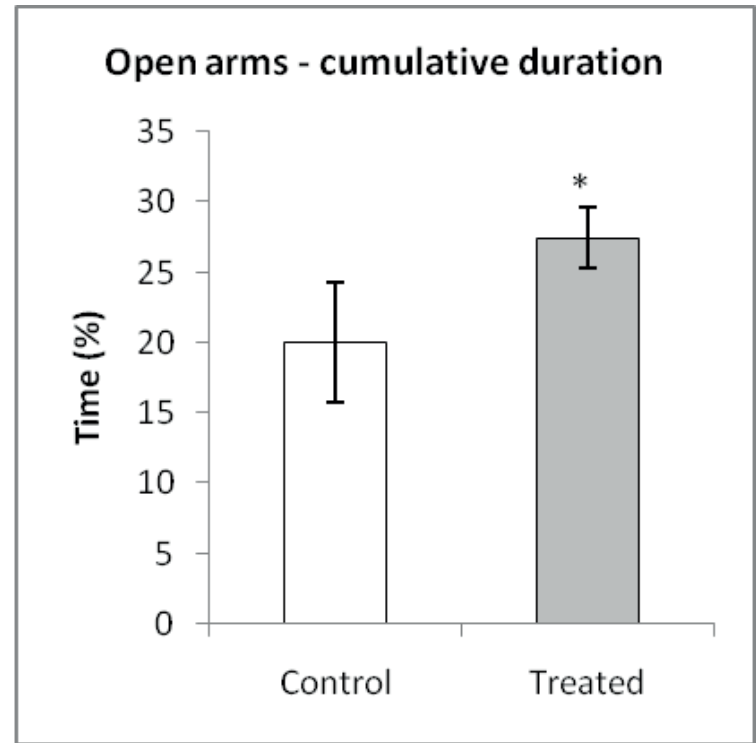

Figure 3. Parameters calculated from the elevated plus maze test (Mean \pm SEM, * denotes significant difference $p<0,05)$. The food intake was completely restricted for $48 \mathrm{~h}$ in the treated animals.

\section{Video recording system and analysis}

All tests were recorded using a digital video camera (Practika DVC 5.10 FHD). Video files (MPEG-2 format) were analysed using Ethovision software [version XT 10 base], an integrated video tracking system for automatically recording the activity, movement and interactions of animals [Noldus Information Technology, the Netherlands] (29).

\section{Statistical analysis}

The results are expressed as the mean $\pm \mathrm{SE}$, and $P$ values $<0.05$ were considered significant in all tests. When two groups of animals were compared, analysis was performed with an unpaired student $t$ test. Nonparametric Mann-Whitney U tests were used for comparisons between groups that did not follow normal distribution. Variables were checked for normal distributions of the data using the
Shapiro-Wilks test. A confidence level of $95 \%$ was accepted as significant. Analysis was performed using SPSS version 20.0 statistical package (IBM SPSS Statistics 20).

\section{RESULTS}

\section{Open field test}

This study showed significant effects from the 48 hours of totally restricted food intake on most of the open field test parameters in the restricted rats compared with the control rats. The total distance moved (Fig. 2A, $\mathrm{p}<0.05$ ), velocity (Fig. 2B, $\mathrm{p}<0.05$ ), movement (Fig. $2 \mathrm{C}, \mathrm{p}<0.05$ ) and frequency in the centre zone (Fig. 2D, $\mathrm{p}<0.05)$ were significantly higher in the treated group. The cumulative duration in the centre zone (Fig. 2E) was not significantly increased in the treated group. 
A

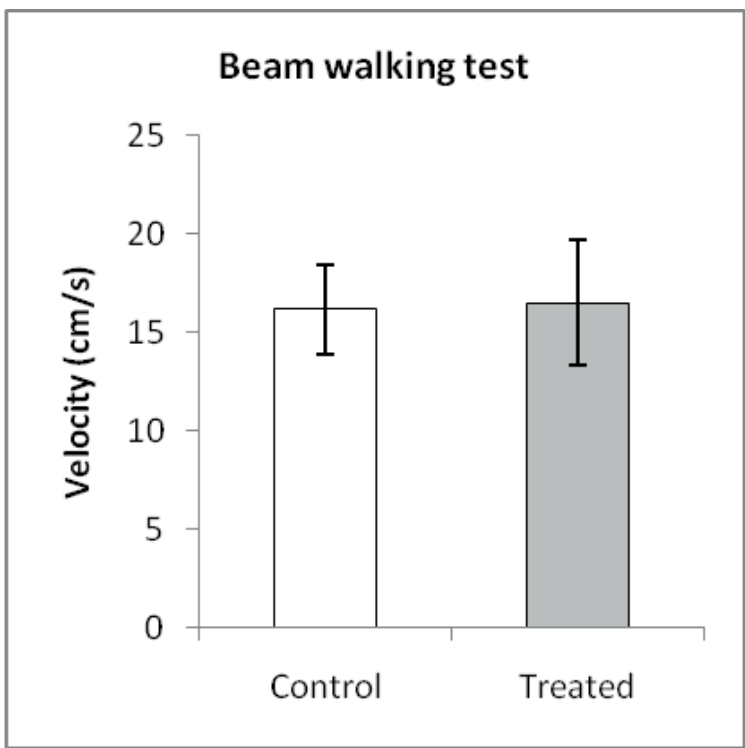

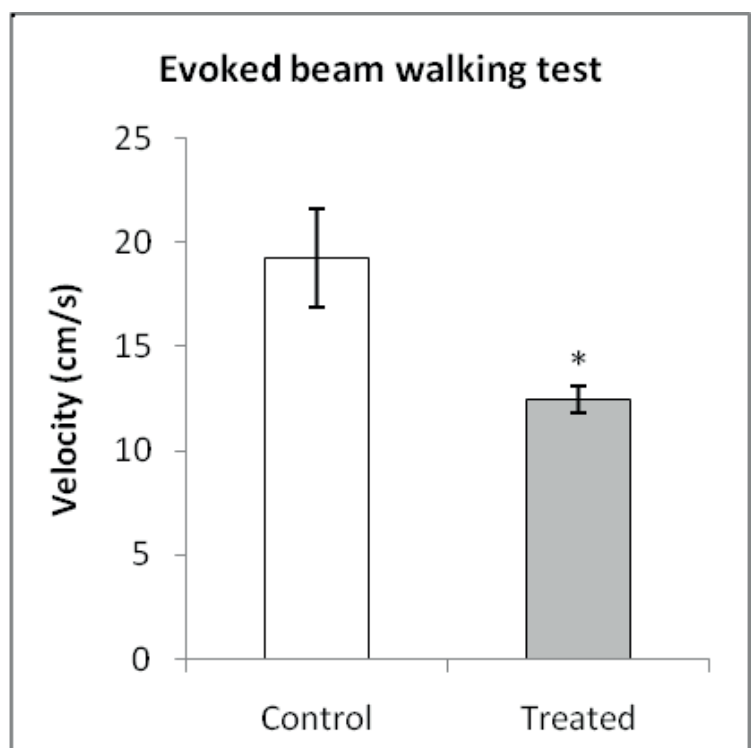

Figure 4. Parameters calculated from the beam walking and evoked beam walking tests

(Mean \pm SEM, * denotes a significant difference $p<0.05)$. The food intake was completely restricted for $48 \mathrm{~h}$ in the treated animals.

\section{Elevated plus maze}

Most of the elevated plus maze test parameters in the rats with total food restriction showed significant changes compared with the parameters for the control rats. The number of entries (frequency) into the open arms (Fig. 3A, p<0.05), the total time spent in the open arms (cumulative duration) of the maze (Fig. 3B, p<0.05) and the total distance moved (Fig. 3C, $\mathrm{p}<0.05$ ) were significantly increased in the treated group compared with the control group. The velocity (Fig. 3D) was not significantly increased in the treated group.

\section{Barnes maze}

The time to find the escape box in the first run was significantly lower than the time to find the escape box in the second run for both the treated and control groups (Tab. 1). Additionally, the distance to find the escape box in the first run was significantly lower than the distance to find escape box in the second run for both groups (Tab. 1). The velocity in the first run was not significantly different from the velocity in the second run for both groups (Tab. 1).

This study did not show significant effects on the Barnes maze test parameters when comparing the rats with 48 hours of total restriction of food intake with the control rats. The percentage of shortening of the distance moved to the escape box between two runs (36.72 \pm 10.35 in the treated group and $31.72 \pm 9.28$ in the control group), as well as the percentage of shortening of the time to find the escape box between two runs (43.48 \pm 10.54 in treated group and $42.99 \pm 8.97$ in control group), did not significantly change. Additionally, the percentage increase in the velocity between two runs $(19.18 \pm 6.21$ in the treated group and $26.24 \pm 11.72$ in control group) did not significantly change.

\section{Beam walking test}

Our results showed that there were no forelimb and hind limb faults or falls from the beam in either of the two groups. Additionally, there was no significant change in the velocity between the food-restricted and control groups (Fig. 4A).

\section{Evoked beam walking test}

There were no forelimb and hind limb faults or falls from the beam recorded in either of the two groups. However, the velocity significantly decreased in the treated group compared with the control group (Fig. $4 \mathrm{~B}, \mathrm{p}<0.05$ ).

Table 1. Parameters calculated from the Barnes maze test.

\begin{tabular}{|c|c|c|c|c|c|c|}
\hline & \multicolumn{2}{|c|}{ Distance to findescape box } & \multicolumn{2}{c|}{ Time to find escape box } & \multicolumn{3}{c|}{ Velocity } \\
\hline & Run 1 & Run 2 & Run 1 & Run 2 & Run 1 & Run 2 \\
\hline Control & $72.15 \pm 11.54$ & $37.76 \pm 8.47^{*}$ & $319.91 \pm 54.25$ & $16.16 \pm 38.67 *$ & $5.79 \pm 1.47$ & $6.59 \pm 2.58$ \\
\hline Treated & $51.91 \pm 8.21$ & $21.26 \pm 6.23 *$ & $198.61 \pm 37.24$ & $100.66 \pm 31.78 *$ & $4.72 \pm 1.32$ & $5.37 \pm 3.64$ \\
\hline
\end{tabular}

$($ Mean \pm SEM, * denotes a significant difference $p<0.05)$. Food intake was completely restricted for $48 \mathrm{~h}$ in the treated animals. 


\section{Linear locomotor test}

There was no significant difference in the velocity $(15.52 \pm 1.74$ in the treated group and $15.11 \pm 2.71$ in the control group) and the zone transitions frequency (3.4 \pm 1.2 vs. $2.8 \pm 1.5$, respectively) between the treated and control groups.

\section{DISCUSSION}

Food intake restriction has been reported to induce various behavioural effects in rats. However, there are substantial differences when considering the overall consequences of starvation on numerous behavioural parameters. Food restriction has been performed in various forms (acute and chronic manner, young and adult animals, different sexes, and different levels of limitation); thus, the type of protocol may be one of the reasons for the inconsistent results among numerous reports.

In the present study, the main findings are that after $48 \mathrm{~h}$ of total food restriction, the rats exhibited anxiolyticlike behaviour. This pattern of behaviour was recorded in a variety of behavioural tests for evaluating anxiety, such as the open field test, the elevated plus maze and the evoked beam walking test.

In the open field test, our results showed anxiolytic-like behaviour, which is confirmed by the increased time spent in the central zone, as well as the higher frequency of entry into the central zone (30). This finding, along with the higher total distance moved by the food-restricted animals and the additional movement, is consistent with the results of Levay (31), who showed that calorie restriction induces increases in the time spent in the central zone and the number of central zone entries. However, these findings in the open field test cannot be solely attributed to anxiety-like behaviour because food deprivation has been found to increase activity in male rats (10); this activity is reflected as increased motor activity, exploration and/or anxiety. The main effect of food deprivation in male rats is the changed behaviour indicated by increased exploration and reduced anxiety (22).

The results of the elevated plus maze test indicate that short-term food restriction can increase motor activity, as well as the time spent in the open arms. These data are consistent with the results of Genn, who showed that male rats have an apparent anxiolytic response in the elevated plus maze test (22). Increased open arm exploration may be considered a food-seeking behaviour. Inoue (32) also showed that the time spent in the open arms is higher in the food deprivation group, corroborating our results. A higher level of explorative activity in the open arms was also reported for the animals with food restriction (33). The increase in the time spent in the open arms might be hypothesised to result from enhanced motivation to forage for food (32). These findings do not correlate with Levay (31), whose elevated plus maze test results were opposite to both our results and previous results in the literature $(33,22,32)$.

Our results for the Barnes maze test showed no effect of acute starvation on the spatial and/or short-term memory of the rats. This finding is in accordance with Mahdavi (13), who reported that food restriction for two weeks did not affect the spatial memory in the Y maze test. Moreover, a long-lasting ( 25 months) reduction of food intake (50\% reduction of fats, $35 \%$ reduction of carbohydrates) has been reported to slow down the weakening of both the reference and working memory that accompanies with ageing (35).

The beam walking test results suggest that the total food restriction for 48 hours did not affect the motor coordination or the balance performance. Because the literature does not contain data on the influence of food restriction on beam walking test results, we can only note that the short-term starvation in our test did not produce an immediate impairment of either motor coordination or balance performance.

Although the beam walking test showed no effects of food restriction on motor coordination and balance performance, the evoked (with anxiety-provoking stimuli) beam walking test results clearly showed anxiolytic-like behaviour in the rats with total food restriction. The velocity decrease in the evoked beam walking test may be, at least partially, due to food-seeking behaviour in the tested group of animals.

The linear locomotor test results provide no evidence for an impairment of motor coordination and motor skills after total food restriction for 48 hours. The results of this test were not previously reported in the literature; thus, we can only compare these results with the results of the beam walking test (indicators of motor coordination and balance performance) and conclude that acute food restriction did not produce prompt alterations in motor coordination and motor skills.

In summary, short-term total food restriction for 48 hours did not produce significant changes in motor coordination, motor skills, balance performance and velocity. However, the food restriction resulted in anxiolytic-like behaviour accompanied by food-seeking behaviour due to enhanced motivation to forage for food.

\section{ACKNOWLEDGEMENTS}

This work was supported by the Faculty of Medical Sciences (JP 01/13), University of Kragujevac, Serbia.

We thank Mr. Mirko Mijanovic for valuable technical assistance.

\section{REFERENCES}

1. Fontana L, Partridge L, Longo VD. Extending healthy life span - from yeast to humans. Science. 2010;328(5976):321-6.

2. Sohal RS, Forster MJ. Caloric restriction and the aging process: a critique. Free Radic Biol Med. 2014;73C:366-382.

3. Hursting SD, Lavigne JA, Berrigan D, Perkins SN, Barrett JC. Calorie restriction, aging, and cancer prevention: mechanisms of action and applicability to humans. Annu Rev Med. 2003;54:131-52. 
4. Jackness C, Karmally W, Febres G, Conwell IM, Ahmed L, Bessler M, McMahon DJ, Korner J. Very low-calorie diet mimics the early beneficial effect of Roux-en-Y gastric bypass on insulin sensitivity and $\beta$-cell Function in type 2 diabetic patients. Diabetes. 2013;62(9):3027-32.

5. Weiss EP, Fontana L. Caloric restriction: powerful protection for the aging heart and vasculature. Am J Physiol Heart Circ Physiol. 2011;301(4):H1205-19.

6. Pallavi R, Giorgio M, Pelicci PG. Insights into the beneficial effect of caloric/dietary restriction for a healthy and prolonged life. Front Physiol. 2012;3:318.

7. Willette AA, Coe CL, Colman RJ, Bendlin BB, Kastman EK, Field AS, Alexander AL, Allison DB, Weindruch $\mathrm{RH}$, Johnson SC. Calorie restriction reduces psychological stress reactivity and its association with brain volume and microstructure in aged rhesus monkeys. Psychoneuroendocrinology. 2012;37(7):903-16.

8. Koubova J, Guarente L. How does calorie restriction work? Genes Dev. 2003;17(3):313-21.

9. Ross MH. Length of life and nutrition in the rat. J Nutr. 1961;75:197-210.

10. Heiderstadt KM, McLaughlin RM, Wright DC, Walker SE, Gomez-Sanchez CE. The effect of chronic food and water restriction on open-field behavior and serum corticosterone levels in rats. Lab Anim. 2000;34(1):20-8.

11. Mathews JR SR and Finger FW. Direct observation of the rat's activity during food deprivation. Physiol Behav. 1966;1:85-88.

12. Rajab E, Alqanbar B, Naiser MJ, Abdulla HA, AlMomen MM, Kamal A. Sex differences in learning and memory following short-term dietary restriction in the rat. Int J Dev Neurosci. 2014;36:74-80.

13. Mahdavi MR, Roghani M, Khalili M, Dalir R. The effects of food restriction on learning and memory of male wistar rats: a behavioral analysis. Basic Clin Neurosci. 2009;1(2):20-23.

14. Adams MM, Shi L, Linville MC, Forbes ME, Long AB, Bennett C, Newton IG, Carter CS, Sonntag WE, Riddle DR, Brunso-Bechtold JK. Caloric restriction and age affect synaptic proteins in hippocampal CA3 and spatial learning ability. Exp Neurol. 2008;211(1):141-9.

15. Allgulander C. Generalized anxiety disorder: What are we missing? Eur Neuropsychopharmacol. 2006;16 Suppl 2:S101-8.

16. Steimer T. The biology of fear- and anxiety-related behaviors. Dialogues Clin Neurosci. 2002;4(3):231-49.

17. Hall CS. Emotional behavior in the rat. III. The relationship between emotionality and ambulatory activity. J Comp Psychol, 1936;22(3):345-352.

18. Ramos A, Mormède P. Stress and emotionality: a multidimensional and genetic approach. Neurosci Biobehav Rev. 1998;22(1):33-57.

19. Prut L, Belzung C. The open field as a paradigm to measure the effects of drugs on anxiety-like behaviors: a review. Eur J Pharmacol. 2003;463(1-3):3-33.

20. Pellow S, Chopin P, File SE, Briley M. Validation of open:closed arm entries in an elevated plus-maze as a measure of anxiety in the rat. J Neurosci Methods. 1985;14(3):149-67.

21. Almeida SS, Garcia RA, de Oliveira LM. Effects of early protein malnutrition and repeated testing upon locomotor and exploratory behaviors in the elevated plusmaze. Physiol Behav. 1993;54(4):749-52.

22. Genn RF, Tucci SA, Thomas A, Edwards JE, File SE. Age-associated sex differences in response to food deprivation in two animal tests of anxiety. Neurosci Biobehav Rev. 2003;27(1-2):155-61.

23. Kenny R, Dinan T, Cai G, Spencer SJ. Effects of mild calorie restriction on anxiety and hypothalamic-pituitary-adrenal axis responses to stress in the male rat. Physiol Rep. 2014;2(3):e00265.

24. Pellow S, File SE. Anxiolytic and anxiogenic drug effects on exploratory activity in an elevated plus-maze: a novel test of anxiety in the rat. Pharmacol Biochem Behav. 1986;24(3):525-9.

25. Barnes CA. Memory deficits associated with senescence: a neurophysiological and behavioral study in the rat. J Comp Physiol Psychol. 1979;93(1):74-104.

26. Morris R. Developments of a water-maze procedure for studying spatial learning in the rat. J Neurosci Methods. $1984 ; 11(1): 47-60$.

27. Chen J, Li Y, Wang L, Zhang Z, Lu D, Lu M, Chopp M. Therapeutic benefit of intravenous administration of bone marrow stromal cells after cerebral ischemia in rats. Stroke. 2001;32(4):1005-11.

28. Ohlsson AL, Johansson BB. Environment influences functional outcome of cerebral infarction in rats. Stroke. 1995;26(4):644-9.

29. Noldus LP, Spink AJ, Tegelenbosch RAJ. EthoVision: A versatile video tracking system for automation of behavioral experiments. Behav Res Methods Instrum Comput. 2001;33(3):398-414.

30. Kalueff AV, Tuohimaa P. Experimental modeling of anxiety and depression. Acta Neurobiol Exp (Wars). 2004;64(4):439-48.

31. Levay EA, Govic A, Penman J, Paolini AG, Kent S. Effects of adult-onset calorie restriction on anxiety-like behavior in rats. Physiol Behav. 2007;92(5):889-96.

32. Inoue K, Zorrilla EP, Tabarin A, Valdez GR, Iwasaki S, Kiriike N, Koob GF. Reduction of anxiety after restricted feeding in the rat: implication for eating disorders. Biol Psychiatry. 2004;55(11):1075-81.

33. Almeida SS, de Oliveira LM, Graeff FG. Early life protein malnutrition changes exploration of the elevated plus-maze and reactivity to anxiolytics. Psychopharmacology (Berl). 1991;103(4):513-8.

34. Means LW, Higgins JL, Fernandez TJ. Mid-life onset of dietary restriction extends life and prolongs cognitive functioning. Physiol Behav. 1993;54(3):503-8.

35. Pitsikas N, Algeri S. Deterioration of spatial and nonspatial reference and working memory in aged rats: protective effect of life-long calorie restriction. Neurobiol Aging. 1992;13(3):369-73. 